\title{
Pastoral juxtaposition in spiritual care: Towards a caregiving faith theology in an evangelical Christian context
}

\begin{tabular}{|c|c|}
\hline \multicolumn{2}{|c|}{$\begin{array}{l}\text { Authors: } \\
\text { Victor Counted } d^{1,2} \\
\text { Joe R. Miller }\end{array}$} \\
\hline \multicolumn{2}{|c|}{$\begin{array}{l}\text { Affiliations: } \\
{ }^{1} \text { School of Social Sciences and } \\
\text { Psychology, Western Sydney } \\
\text { University, Australia }\end{array}$} \\
\hline \multicolumn{2}{|c|}{$\begin{array}{l}{ }^{2} \text { Department of Practical } \\
\text { Theology and Missiology, } \\
\text { Stellenbosch University, } \\
\text { South Africa }\end{array}$} \\
\hline \multicolumn{2}{|c|}{$\begin{array}{l}{ }^{3} \text { Applied Theology and } \\
\text { Leadership, Southern } \\
\text { California Seminary, } \\
\text { United States }\end{array}$} \\
\hline \multicolumn{2}{|c|}{$\begin{array}{l}\text { Corresponding author: } \\
\text { Victor Counted, } \\
\text { v.counted@westernsydney. } \\
\text { edu.au }\end{array}$} \\
\hline \multicolumn{2}{|c|}{$\begin{array}{l}\text { Dates: } \\
\text { Received: } 03 \text { May } 2017 \\
\text { Accepted: } 08 \text { Sept. } 2017 \\
\text { Published: } 31 \text { May } 2018\end{array}$} \\
\hline \multicolumn{2}{|c|}{$\begin{array}{l}\text { How to cite this article: } \\
\text { Counted, V. \& Miller, J.R., } \\
\text { 2018, 'Pastoral juxtaposition } \\
\text { in spiritual care: Towards a } \\
\text { caregiving faith theology in } \\
\text { an evangelical Christian } \\
\text { context', HTS Teologiese } \\
\text { Studies/Theological Studies } \\
\text { 74(2), a4630. https://doi.org/ } \\
\text { 10.4102/hts.v74i2.4630 }\end{array}$} \\
\hline \multicolumn{2}{|c|}{$\begin{array}{l}\text { Copyright: } \\
\text { (C) 2018. The Authors. } \\
\text { Licensee: AOSIS. This } \\
\text { is licensed under the } \\
\text { Creative Commons } \\
\text { Attribution License. }\end{array}$} \\
\hline \multicolumn{2}{|l|}{ Read online: } \\
\hline 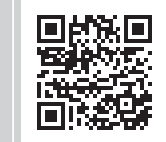 & $\begin{array}{l}\text { Scan this QR } \\
\text { code with your } \\
\text { smart phone or } \\
\text { mobile device } \\
\text { to read online. }\end{array}$ \\
\hline
\end{tabular}

The problem for many troubled youths seeking help within a Christian context is that their need for meaningful connections and spiritual growth is attached to relationships with their significant others. When needs of attachment are not adequately met due to the effect of an insecure attachment working model in a relationship with God, the teen may end up leaving the faith community seeking a new caregiver or regress into spiritual struggles, depression, anxiety, self-doubt and other negative emotions. This paper responds to the issues associated with youth attachment behaviour towards God using a caregiving theology (i.e. pastoral juxtaposition) that draws on the 'power of two' through incarnational creativity and pneumatological ecclesiology. This proposed theology first supplements the work of the pastoral counsellor to create a transformative container through which young people, already within a redemptive Christian community, can grow spiritually and deepen their relationship with God. Secondly, pastoral juxtaposition targeting the spiritual needs of hurting youths serves to create a magnet space within the church community that models incarnational love, pastoral care and support for young people by entering their world order to reframe their personal stories of grief, abandonment and insecurity through creative means. Finally, we theologise that pastoral juxtaposition also integrates the power of the Holy Spirit, as the ultimate caregiver in times of conflict, into each youth's unique journey of faith and healing. Implications of this pastoral theology are discussed and applied to everyday life.

\section{Introduction}

This article draws heavily on the first author's research on youth faith formation of South African Christian youths (e.g. Counted 2016a; 2016b; Counted \& Moustafa 2017) to offer a pastoral response to the 'pattern of youth attachment behaviour towards God in which the young person emphasizes the importance of needing care and emotional support in their faith experience' (Counted 2016a:167). In a typical faith development scenario in young people's pursuit of emotional security, God becomes the proximal attachment figure and a reliable caregiver in the absence of a parent or a relational other. This faith development perspective is very much nuanced in psychology of religion literature (e.g. Granqvist \& Kirkpatrick 2016; Kirkpatrick 1992; 1998) and draws on insights from Bowlby's $(1969 ; 1988)$ attachment theory. The attachment-religion connection has been discussed as an aspect of adult attachment development (Cicirelli 2004), with its goal being to achieve a sense of 'felt security' with the knowledge of the whereabouts of God as a symbolic object of attachment through means of religious attachment behaviours such as reading the Scripture, seeking God through prayer and participating in religious activities that draw one closer to God (Granqvist \& Kirkpatrick 2016; Kirkpatrick 1992; 1999). However, the problem with this kind of youth faith development is that it is not grounded. When God is perceived to be distant or not answering prayers, this may lead to a separation anxiety as some youth search for a new 'caregiver' because their needs for attachment are not adequately met.

While there is difficulty in defining every socio-psychological factor involved, this kind of religious attachment can serve as an opportunity for evangelical Christian communities (and other Christian communities) to increase their involvement in fostering a deeper caregiving environment. The term 'evangelical' itself is often poorly defined and used broadly in different research. In this paper, the term 'evangelical' will be understood as the modern Christian movement that is not defined by any one nationality, race, denomination or political affiliation. Evangelicalism is the collection of Christian believers across a broad spectrum who take seriously the content of the Judeo-Christian Scriptures, the need for social activism and the missional imperative to share the good news of

Note: This article is published in the section Practical Theology of the Society for Practical Theology in South Africa. 
Jesus with the world. However, applying attachment theory to the evangelical mission is not a simple task. As noted by the 21st century theologian Carl F.H. Henry, 'Evangelical theology, on the other hand, while preserving the Judeo-Christian verities all too often fails to project engagingly upon presentday perplexities' (1999:10). Recognising the challenges of integrating historic evangelical vocabulary with contemporary psychological theory, this paper makes a case for integration of the Christian community into the individual youth's spiritual growth programme and proposes a pastoral theology of juxtaposition as a framework of support to young people longing for a caregiving God who can help them not only to overcome their past, but also to adjust to a new reality (Clinton, Hart \& Ohlschlager 2009). Drawing on Shenk's $(2014 ; 2015)$ treatment of the principle of juxtaposition, the authors propose in this paper a pastoral juxtaposition which stresses the need for the 'powers of two' in creating both relationships and opportunities that foster spiritual growth within the context of a church community. Pastoral theology of juxtaposition seeks to help the conflicted youth by identifying with them as Christ did through his incarnation. This incarnation process allows the pastoral counsellor or church community to validate the struggles of the conflicted youth by charging into their lives through the gifts of the Holy Spirit who stands as the advocate of those drawn to God, directing and guiding the youth in their walk with God.

\section{Attachment theory and youth caregiving faith experience}

British psychoanalyst Bowlby $(1969 ; 1988)$ came up with an evolutionary theory of attachment that suggests that children are biologically pre-programmed to form attachments with others to help them survive in and engage the world around them. He postulated that behavioural problems and tendencies could be attributed to early childhood years. This notion of attachment was very much influenced by the work of Lorenz (1935), who had earlier argued that attachment was an innate experience and thus has a survival value. In drawing theoretical insights from Lorenz, Bowlby $(1969 ; 1988)$ reasons that attachment behaviours are instinctive and are therefore activated when a child is afraid and perceives their social environment as being insecure or senses separation from their caregiver. When separated from an attachment figure, the child seeks a surrogate attachment to act as a secure base for their development and personal growth, or a safe haven to turn to in times of perceived danger. Attachment with a primary caregiver functions as a prototype for all future relationships and disrupting such early attachment can have severe consequences for the child (Kobak, Zajac \& Madsen 2016). Kobak and colleagues believe that a child should receive the continuous care and support from the attachment figure because separation from such caregiver can lead to distress and emotional turmoil. Although Bowlby largely assumed an evolutionary perspective in his focus on the attachment behavioural system and its manifestation in a child's relationship with the parents, he stressed that attachment processes may have a broader implication for future psychological developments and relationships.
Over time, the attachment relationship with a primary caregiver forms what Bowlby $(1969,1988)$ referred to as the 'internal working model' of the attachment behavioural system, which is a cognitive framework for understanding self, others and the world-at-large. In other words, the social behaviour of a person is guided by their personal relationships, biographies, memories and expectations, as a result of their attachment working model from which they evaluate and direct their relationships with others (Bretherton \& Munholland 1999). It is on this basis that several non-traditional applications of attachment theory have been proposed, exploring attachment to God (Counted 2016a, 2016b; Counted \& Moustafa 2017; Granqvist \& Kirkpatrick 2016; Granqvist et al. 2010; Hall et al. 2009; Rowatt \& Kirkpatrick 2002), attachment to romantic partners (Holmes 2009; Hudson et al. 2014), attachment to place (Counted \& Watts 2017; Scannell \& Gifford 2010) and attachment to workplace (Hardy \& Barkman 1994; Hazan \& Shaver 1990). The application of attachment theory in understanding broader perspectives of social relationship dynamics is, arguably, without limit. Albeit scholars should take caution not to extend the concept of attachment beyond its valid limits because one weakness of attachment theory is that it lacks theoretical resources for helping one identify inauthentic attachments. This is where the idea of faith development in terms of attachment relationship with God, in the context of the evangelical Christian community, seems plausible on the basis that:

The idea of God is the idea of an absolutely adequate attachment figure ... God is thought of as a protective and caring parent who is always reliable and always available to its children when they are in need. (Kaufman 1981:67)

Kimbell (2001:354-355) argue for this methodology, writing that:

Attachment theory helps us to understand how wounded parents bring their ghost into parenting. It provides one explanation of the way in which the 'sins of the parents are passed down unto the fourth generation' (Num 14:18). We need the church family to re-parent us and to help us find our value, so that we as parents might better help our children see their value. And the church's concern must go beyond simple dyadic (mother-child, father-child) relationships. God calls the church to participate in the nurturing and parenting of our children. This is a direct response to God's call for the church family to be a holy, loving community. (Col 3:12-17)

Attachment theory was recently applied in a study (e.g. Counted 2016a; 2016b; Counted \& Moustafa 2017) with South African Christian youths, from which Counted (2016a) described youth faith experience as an attachment experience and a 'caregiving faith' in which youth develops an attachment behaviour towards God who is perceived as a symbolic attachment figure in times of emotional separation from a primary caregiver. In this kind of faith experience, the young person emphasises the importance of emotional support and the need for a divineomnipresent caregiver. Other studies (e.g. Hall et al. 2009; Kirkpatrick 1992; 1998; 1999) also support this notion of a caregiving faith development and the idea that attachment experiences with primary caregivers can be linked to faith experiences and the desire for God among people of faith. 
The idea of a caregiving faith experience is not new in psychoanalytic theory. Sigmund Freud first proposed similar understanding of religion in his account on the origin of religion, where he recognised God as a kind of fictionalised parental figure (Freud 1927; 1961). However, by focusing only on the developmental deficit that leads to distorted beliefs about origins of faith experience, Freud's argument is flawed by a genetic fallacy (judging a phenomenon based on its origins) because one can experience God in adolescence and adulthood as an attachment surrogate as a meaningful source of hope, protection, and security, thereby disproving Freud's discrediting of religious faith. Other post-Freudian psychoanalytic traditions took a different turn on religion and were more open towards religion, while also positioning it as a 'childish' behavioural pattern that narrates the story of a religious believer's need for emotional security. PostFreudian psychoanalytic debate on religion moved away from the initial 'Freud's instinctual model of human motivation and replaces it with an essentially relational vision of human beings' (Jones 1996:24). This rethinking of relational paradigm began with the work of Fairbairn (1952) who introduced object relations theory, a theory later adopted by Rizzuto (1979) to further develop Freud's thesis on the origins of religion. Rizzuto moved away from the Freudian notion of God as an internally generated object to that of an object relations model, which positions religion as an experiential knowledge of the Divine in terms of a believerGod relationship and representations that are captured in a variety of relational God images and schemas. The object relations approach to religion conveys an idea of a relational model of human nature, giving rise to Bowlby's (1969) development of attachment theory that eventually emerged out of the debate on post-Freudian psychoanalytic theory. Kirkpatrick and Shaver (1990) (also see Kirkpatrick 1992) first introduced the concept of religion as an aspect of attachment experience that considers the affectional bond between a religious believer and their divine attachment figure.

These historical concerns in terms of Freudian psychoanalytic account to religion have resulted in resistance to utilising attachment theory within the evangelical Christian context. Despite these concerns, a sufficient body of research supports the existence of an attachment to God as an articulation of a caregiving faith within a variety of faith communities, having implications for mental health and psychological outcomes (e.g. Bradshaw et al. 2010; Ellison et al. 2014). The idea of a personal relationship with God in Christian contexts accounts for how 'the attachment system provides a means for making God's presence to us more immediate, personal, and concrete' (Boccia 2011:24). In addition, the application of attachment theory to faith development 'may help us to understand experiences reflected throughout the history of the church and captured with phrases such as "dark night of the soul", or "wilderness experience"' (2011:24). The meanings attached to such experience may very much outweigh the history on individual basis. As a symbolic attachment figure, proximity to God can be expressed through various channels of religious attributions in diverse spiritual healing contexts such as prayer, reading religious texts, rituals and meditation
(Williams \& Watts 2014). A 'caregiving faith' is therefore a phrase used to describe a spiritual experience which precipitates from the internal working model in the attachment behavioural system of the individual. Counted (2016a, 2016b) conducted interviews with young people between the ages of 18 and 35 who developed this kind of caregiving faith, many of whom had experienced emotional difficulties, attachment separation and abandonment relating with their primary caregivers - mostly their parents.

As an illustration, Counted (2016a; 2016b) tells the story of Josiah who was passionate about his education and determined to make the best out of life, but his father was an alcoholic; he was often not home, or if he was, he was either drunk or depressed. When Josiah was in Grade 11 and getting ready for his matric exams, his mother was critically ill, which meant that neither parent was able to provide him with the emotional support he needed when preparing for his exams. Reaching out for a secure relationship with someone that was not out of reach, Josiah found God, yet still struggles with feelings of anxiety about God abandoning him just as his biological parents did. He constantly feels that he is unworthy of God's love and needs to do more to please him, even though he comes to church regularly and prays from time to time. Another story shared in the study was that of June, who was abandoned by her mother who had left for London to support her family when she was in grade 1 and just about 8 years old. The physical and emotional impact this had on her during her formative years has made her wary of allowing people into her life and forming attachments. Her fear of being hurt again led her to finding God, whom she feels will always be there for her in a way which her mother was not. Nevertheless, she still experiences feelings of anxiety, despite acknowledging that:

I want to have this relationship [with God] ... and get myself again. I am not there where I wanted to be. I know it is important in one's life. I know what miracles God can do if He is in your life. (Counted 2016a:162)

Now a university student, June often kneels in prayer to God, hoping she will fill the void in her.

The stories of Josiah and June are only two examples of how negative experiences with a caregiver (whether it be a parent, a friend or any other person with whom we have had an emotional attachment) can have a profound effect on how we perceive ourselves and desire others. The two stories have one thing in common: they show how experiences with primary caregivers establish the model for exploring self and desiring God. This model is seen regulating the attachment behaviours of Josiah and June, and many other youths, as they sought a relationship that would heal the wounds of their past and attend to their need for care and quality attachment. These kinds of emotional compensation experiences have been substantively studied in attachment to God research as the first pathway to faith development among insecurely attached individuals (e.g. Counted 2016a; Hall et al. 2009; Kirkpatrick 1998; 2005). This first pattern shows how the caregiving faith of young people is developed 
following experiences of abandonment and emotional betrayal with insensitive caregivers.

The second pattern observed in the study (i.e. Counted 2016a) saw securely attached South African Christian youths developing perceived connections with God as a surrogate attachment even though they had sensitive caregivers. One such story is that of Marley who left her family home for her first year of university studies. Although she seems to have a secure attachment with her parents, she formed a relationship with God after she had moved from home for her studies. Having a relationship with God seems to enhance the emotional security that Marley already enjoys with her parents. This faith development pathway has been extensively studied in attachment to God research as the correspondence hypotheses (e.g. Counted 2016a; Kirkpatrick 1998, 2005; Kirkpatrick \& Shaver 1992). In both pathways, there is a sudden need to navigate the relational world and develop an attachment with someone (or something) stronger and wiser among the youths, thus allowing their attachment goals and perception of others to permeate their relationship with God. The need for caregiving is justified because of the difficult or secure experiences with primary caregivers, most of whom happened to be family members (especially their parents), serving as a security-enhancing or affect-regulating experience. However, data evidence in the study with South African Christian youths (e.g. Counted 2016a; 2016b) suggests that young people are more likely to compensate for the 'abusive' relationships experienced with their parents by turning to God as a surrogate attachment. The consequence of having abusive and dysfunctional family relationships is that the abused often respond by developing insecure coping styles such as being anxious, dismissive, fearful or even abusive, in order to block their conflicting and shameful past experiences (O'Keefe 1995; Schumacher \& Leonard 2005). On the other hand, others may seek for a surrogate attachment in another potential caregiver like God to heal the wounds of their past and inspire a sense of hope for a healthy future.

When young people are deprived of love and care they are more likely to search for it elsewhere. Some find it in their romantic partner, school, workplace, fraternity and friends or in any object or person that they think can be a reliable source of support to them. Some end up finding this advantage in God. They are in a relationship with God because he is perceived as a caregiving figure who can fill the void of a lost or abusive attachment with his radiant love and presence. The idea of the existence of God as a caregiving figure is also theologically grounded. The Bible tells a relational story of God's love for humanity, one which has been expressed to his creation through the incarnation of Christ, and the sending of the Holy Spirit in continuation of the communion fellowship with the Trine God (Bosch 1991). God reveals himself as a caregiver to those drawn to him offering comfort, protection and security for believers (Granqvist \& Kirkpatrick 2016). This relational attribute of the Christian faith suggests that the notion of attachment is central to Christian theology, as it binds most believers to a caregiving God who is perceived as stronger, wiser, all-knowing, holy, a haven of safety and secure base, and one from whom separation may trigger negative emotions. In the Bible, God is often referred to the as the protector of the saints (e.g. Ps 127:1; Ps 54:4), a friend closer than a brother (e.g. Pr 18:24), a way maker (e.g. Is. 43:16-19), the greatest high priest (e.g. Heb. 4:14-16), among others. No wonder King David referred to God as his 'Shepherd' in Psalms 23. Many other metaphors are used to express this unique attribute of God in the Bible as a caregiving figure for his followers. The 'personification' of God as a caregiving figure demonstrates how he is perceived as an important source of attachment-related 'felt security' among Christian believers (Granqvist et al. 2010; Kirkpatrick 2005).

To further probe the concerns raised in this section, a question that comes to mind could be, 'What happens next after developing a relationship with God because of a separation experience with a primary caregiver?' Counted (2016a) noted in his study that much of the issues young people had with their primary caregivers were also manifested in their new relationship with God. For example, most of the young people who were insecurely attached to their primary caregivers were also insecurely attached to God because the same working model of attachment that was developed during experiences with primary caregivers was also in action when assessing God's existence as an attachment figure. According to the attachment to God theory, individuals who struggle in their relationships with primary caregivers, having insecure working models, are also likely to struggle in their relationships with other objects of attachment (e.g. God) (Kirkpatrick 1999; Richert \& Granqvist 2013). Ano and Pargament (2013) have reported insecure attachment to God as a predictor of spiritual struggles. Hence, even though the relationship with God was used as a means of alleviating the pain and entanglements of past relationships, maintaining and sustaining such relationship would be a difficult hurdle for most of the young people.

Emotional distress and spiritual struggles are often experienced in a caregiving faith experience, particularly when the individual perceives God as being insensitive to their feelings and seeks to make sense of the insecurity they experience in their relationship with God (cf. Counted 2016b; Ellison et al. 2014). This insecurity and emotional tension can often lead to emotional turmoil and spiritual struggles because the psychological and spiritual needs of the youth might not have been immediately met by God (Counted 2016b). The youth, at this stage of making sense of their new relationship with God, begins to explore other social and religious landscapes in search of meaning while simultaneously developing their caregiving faith. For example, they can turn to their church community or role models for acceptance and deeper understanding to help them navigate the compass of their relationship. While it is acknowledged that conflict may help foster autonomy in the youth, attention is also drawn to the mental health implications of forming a caregiving faith experience. Ano and Pargament (2013) have linked insecure attachment with God to spiritual struggles. Counted and Moustafa (2017) report a correlation between insecure attachment with God and feeling out of touch with one's self 
(inauthenticity). Therefore, it is worthwhile exploring a theology of spiritual care that can respond to the youth's caregiving faith development because this kind of faith experience thresholds the beginning phase of a spiritual journey for most youths. However, if the relationship with God is perceived as insecure, wherein God, being the caregiver, is viewed as 'demanding' too much too soon or is perceived to be inaccessible or insensitive, this may also lead to anxiety, spiritual struggles, and doubt about one's ability to maintain such a relationship (Counted 2016b; Shin 2009). Studies (e.g. Counted \& Moustafa 2017; Exline et al. 2013; Ringel 2008; Reinert 2005)) have shown that these negative emotions and perceptions of the self are often shaped within the context of a church community. As a result, the youth may be stuck in a constant state of searching for their identity and maintaining their new unpredictable relationship. This rapid onset of selfconsciousness is the ignition that triggers core questions of identity among young people (Erikson 1968).

\section{Pastoral theology of juxtaposition}

Shenk $(2014 ; 2015)$ in his books on the principle of juxtaposition examines how the relationships between two variables may drive creativity, which, in turn, is used to thrive in conflict. The premise of his argument was that the human brain is wired to collaborate. Hence, even when one is alone, they are in a sense working together with a voice inside their head. He further argues against the idea of solitary genius by drawing on neuroscience and cultural history to demonstrate through his research that the most significant and creative works in human history came from collaboration with a pair as its primary embodiment. Juxtaposition is therefore the act of placing two or more things side-by-side or in close proximity to each other so as to attain a creative space within which a breakthrough can be achieved. The core value of this creative space is the juxtaposition of mutual interests which Shenk (2015) describes as the:

faith, underscored by experience, that more is possible - more intimacy, more creativity, more knowledge about this primary truth: that we make our best work, and live our best lives, by charging into the vast space between ourselves and others. (p. xxv)

Our proposal for pastoral juxtaposition in spiritual care is theorised within the context of evangelical theology. As noted previously, this Christian movement is subject to a variety of definitions from authors of differing traditions. Hunter (1983), for example, defines evangelicalism as a Protestant phenomenon recognised for its theological stance in terms of the inerrancy of Scripture and the divinity of Christ. This definition, however, is unnecessarily limited to the Protestant faith, and within this paper the term 'evangelical' will be understood as encompassing subgroups within both the Protestant and Roman Catholic traditions. Evangelicalism, in this larger context, is the collection of Christian believers across a broad spectrum of faith traditions who take seriously the authority of Bible as God's revelation to mankind and belief that the essence of the Christian faith is founded on the doctrine of salvation through faith in Jesus Christ (The Concise Oxford Dictionary 1978).
In this section, we propose a pastoral theology of juxtaposition to show how the idea of the 'powers of the two' in spiritual care can aid in fostering spiritual growth despite the development of a caregiving faith. Pastoral juxtaposition offers interventions for the spiritual struggles associated with feelings of insecurity in maintaining a relationship with God through reparative trusted relationship with a pastoral counsellor or a church community. We argue that the corrective relationship with a trusted Christian counsellor or church community could transform the nature of the insecure working model of attachment which guides the youth's relationship expectations, enabling the youth to attain greater sense of earned security in their relationship with God. Theoretical insights are drawn from the Christian theology of incarnation and pneumatological ecclesiology, while also demonstrating how stories of God's love can create an atmosphere for the expression of love in terms of building trusted relationships with conflicted youths. Kimball et al. (2013) have proposed that alternative trusted relationships can serve as corrective measures, altering the insecure perception of one's internal working model of attachment. In addition, we propose that working side-by-side with the Holy Spirit as a surrogate attachment is an important second step in pastoral juxtaposition, as will be made clearer.

\section{Incarnational creativity in pastoral juxtaposition}

To engage the youth creatively with the story of Divine love, we argue that the story of incarnation may exert the power to reframe the way young people understand the condition of the world in which they live in terms of their relationship with God (Aden \& Hughes 2002). As discussed in previous sections, an important point of departure for the development of a caregiving faith experience is the 'centrality of the emotion of love in people's perceived relationships with God' (Granqvist \& Kirkpatrick 2016:918). The notion of divine love as expressed in the language of human love is central to the incarnation of Christ. While we reason that the quality of love experienced in the youth-God relationship shares the same semblance with that of a parent-child relationship in terms of attachment processes, we also propose that this quality of love is expressed in the incarnate Christ who embodied the very essence of the principle of juxtaposition by demonstrating his love for the world. This love is captured in the Bible: 'For God so love the world that He gave His only Son, that whoever believes in Him shall not perish but have eternal life' (Jn 3:16).

An incarnational view of pastoral juxtaposition would see a spiritual caregiver embodying their call as helpers of those who are hurting based on the incarnation of Christ as the ultimate 'Servant-Caregiver' (Oden 1992:86). To some extent, the work of a spiritual caregiver mirrors that of the incarnate Christ because the process of spiritual care may require absorbing the youth's relationship distress in fulfilment to the law of Christ in Galatians 6:2 to be burden bearers. This was stressed in the proposition of Benner (1983) who argued that the concept of incarnation may be used as a metaphor for psychotherapy in terms of how pastoral counsellors should 
see their work in general. The bearing of burdens in spiritual care, as Christ did for mankind through his incarnation, may further mean to work with young people who are hurting in the world of danger through the process of projection, transference and resistance. Benner reasoned that this may be the most challenging aspect of being a pastoral counsellor: serving and helping those who would want to take their journey of faith further.

To sustain a healthy incarnational view of pastoral juxtaposition, the pastoral counsellor must also understand the importance of boundaries and healthy relationships with those to which they are called to serve and help in nurturing their faith. The person seeking help should also be encouraged to be independent in their journey of faith, while the counsellor must not get lost in the incarnation process with the conflicted (Benner 1983). Benner reasons that the incarnational view does not allow for an inappropriate dependency on the counsellor, as with God who did not cease functioning as God while he took upon himself a human body as incarnate. In other words, the same way God became 'flesh' in the process of incarnation while still existing as God in humanity is the same way a pastoral counsellor should separate himself or herself while also entering the world of those in conflict. The pastoral counsellor should become like those they help in the practice of pastoral juxtaposition while also remaining who they are in the process as God did when he came into the world to partake in our humanity.

The central evidence of an incarnational practice in pastoral juxtaposition is when the young person who is being helped in their spiritual walk feels a sense of being loved by the counsellor who is both sharing in the struggles of the youth and separating himself/herself from the struggles. Humanity felt this sense of unconditional love through the sacrifices of Christ who made the ultimate sacrifice of love by laying down his life for others to live and have life. While secular counselling practices may also emphasise this sense of relatedness in counselling, the difference with our proposed pastoral juxtaposition in Christian counselling is the root of such kind of love and genuine concern, which is embodied in the life of an incarnate Christ. Embodying incarnational love in spiritual care impresses on the counsellor a sense of deep calling in terms of identifying with the world of a conflicted youth. The incarnational view of pastoral juxtaposition first stresses the importance of entering the world of a conflicted youth to create a magnet space for reframing their experiences. This step starts with developing a genuine sense of identification and relationship with the conflicted youth, a presence rooted in divine love while also partaking in their suffering as the embodiment of the love shown to humanity by an incarnate God.

\section{Pneumatological ecclesiology in pastoral juxtaposition}

The second evidence of pastoral juxtaposition is the leading of the Spirit. In developing our theology of pastoral juxtaposition for spiritual care, we further argue that incarnation is not the only step needed in helping a conflicted youth. Arguably, one of the benefits of Christ's incarnation after his ascension is the Holy Spirit. In the gospel of John 14:15-31, Christ promises his Holy Spirit as an advocate to help us find him in a world of danger and through the process of our spiritual growth. We reason here that it is the duty of the pastoral counsellor to introduce the Spirit of God to a conflicted youth struggling to grow in their relationship with God, without which there is no authentic evidence of pastoral juxtaposition. The Holy Spirit continues the work of pastoral juxtaposition as the intercessor of those who are hurting and in need of help beyond where the pastoral counsellor can go.

Youth caregiving faith is a relationship with a divine attachment figure in the person of Christ, who is God incarnate. In addition to this premise, it is also proposed that an attachment with the Spirit of God, the Holy Spirit, is necessary for a stable and effective spiritual growth. The Holy Spirit should be the ultimate attachment figure, as a revelation of the mystery of the Triune God. This revisits the mission Dei hope as an evidence of God's sending of Jesus Christ who promised the Holy Spirit to his followers to be their advocate in times of troubles (i.e. Jn 14:15-31). For this to take place, the personality of the Holy Spirit must be understood within a strong Trinitarian framework. Kärkkäinen (2002) offers to explain the particulars of pneumatology - the doctrine of the Holy Spirit as a Christian tradition that has been neglected in some traditions. Bruner and Horden (1984) reason that this neglect might be because some have pictured the Holy Spirit as the 'shy' member of the Trinity. Such unfortunate terminology has hindered some from recognising the important work of the Spirit in spiritual formation. Nonetheless, the promise of the Holy Spirit by Christ in the gospel of John is an important aspect of incarnational theology. Similar emphasis on the person of the Holy Spirit is also seen in the Old Testament (see Mi 3:8; Jl 2:28-32; Is 44:3-5; Ezk 36:26-27; 1 Sm 16:12-13; Ps 51:11) and continued through the testimony of Peter in Acts 15:6-11 where he mentioned God pouring out his Spirit to all people regardless of ethnic or national origin (cf. Ac 15:8b). As Miller (2008) notes:

There could be no unified Christian faith if the world were split into Jews and Samaritans; God's plan called for one community, one Body, and one Church. Nothing less than this would serve God's redemptive plan. (p. 164)

Evangelicals have sought to integrate the New Testament spiritual experiences, particularly the presence of the Holy Spirit in creating a unified healing church in the life of the Christian community as the power of God. The presence of the Holy Spirit, as a starting point for spiritual growth, is an important factor for achieving pastoral juxtaposition in Christian counselling within an evangelical context (see Eph 3:16; Benner 2003; Power 1990).

To complete the task of pastoral juxtaposition, the presence of the Holy Spirit in one's life aids in facilitating the process of spiritual growth and maintaining secure attachment with God. It is necessary to refocus attention towards the person of the Holy Spirit, the third person of the Trinity, to deepen 
the youth's understanding of and reliance upon the Spirit of God in their journey of faith. The Holy Spirit continues beyond where the job of the pastoral counsellor stops in terms of nurturing, strengthening and facilitating the spiritual growth process of the youth in such a way that it bears witness to the power of God in the world. The work of the Spirit juxtaposes with that of the pastoral counsellor in helping the youth experience the power of salvation in Jesus and grow in their knowledge of God the Father. Most importantly, the nitty-gritty of pastoral juxtaposition may as well require that the pastoral counsellor have a stable and deep relationship with the Holy Spirit in order to effectively witness to the youth in conflict using the gifts of the Spirit (e.g. word of wisdom, word of knowledge, understanding, counsel, piety, fortitude and the fear of God) (1 Cor 12:7-11).

Having a personal experience with God, the Holy Spirit, filtered through a strong understanding of how the Spirit speaks through the Bible, ${ }^{1}$ is essential for the youth to grow in their caregiving faith. This experience may take several forms but primarily helps the youth enhance their understanding of God, the Father, as the ultimate attachment figure. The pastoral counsellor may as well be responsible for introducing the person of the Holy Spirit to the youth in conflict. This can be achieved through emphasising the importance of the Spirit and acknowledging his person in the incarnational process of juxtaposition.

\section{Pastoral juxtaposition within a redemptive community}

The proposed pastoral juxtaposition is a methodological approach that provides practical insights that recognise incarnation creativity and pneumatological spontaneity as practical steps for advancing the spiritual growth of persons facing mental and spiritual difficulties within an evangelical context. The idea here is to create a transformative space in which one learns much about how to provide spiritual care with the aim of working side-by-side with another and attending to the small details of an individual's life in a spiritual healing context. The individual is encouraged to set aside activities that lead to isolation and replace them with ones that integrate them into the life of a caregiving faith community (Collins 2006). We reason that God first created such creative space through his incarnation, taking a human form to live among men in order to learn much about the human race and to stand as our high priest and the perfector of the Christian faith (cf. Heb 4:14-18). Jesus perfected the art of pastoral juxtaposition in his incarnation process, having 'empathized with our weaknesses, and tempted in every way, just as we are ...' (cf. Heb 4:15) so as to become a better caregiver for us in times of difficulties. The incarnational love reflected in the sacrifice of Jesus, described by Paul in

1.The use of 'Word' in many traditions is often associated only with the written text of the Bible. The authors here subscribe to a more holistic understanding where in addition to the written word, the term refers to the spoken word of the Holy Spirit, the living word of Christ and the manifest word in thok word of the Holy Spirit, the living word of Christ and the manifest word in the church. Adequate knowledg of God's written Word through the spoken word of the Holy Spirit is a potential nex step in pastoral juxtaposition which cannot be fully addressed in the context of this paper. The authors hope to strengthen this way of thinking in the holistic understanding of Word, and as it specifically relates to the knowledge of the Bible juxtaposing with that of the works of the pastoral counsellor and Holy Spirit in helping the youth grow spiritually.
Galatians 3:26-4:7, created not only a hope for the individual, but also a healing community that serves as a surrogate family of brothers and sisters. Hellerman (2009) describes this kind of healing community as one that is part of God's encompassing plan for salvation. In describing salvation as a 'community-creating event', Hellerman (2009:137) contends that 'The idea of salvation cannot be reduced to a personal relationship with Jesus'. This incarnational approach to salvation also demonstrates the Christian ideal that sees leaders and elders within a church community serving as models of stability to be emulated by those in emotional distress (Miller 2017). Although it is conceptualised in terms of incarnational view in our study, Shenk $(2014,2015)$ saw the principle of juxtaposition as the art of listening and learning from one another. This understanding of incarnational creativity can be practiced within a community of faith where everyone is challenged to work with each other, charging into the vast space of isolation and anxiety between one another to contribute to building a healthy church community.

Secondly, pastoral juxtaposition within a redemptive church community also requires pneumatological spontaneity and openness to the Spirit of God who has been released to us to help in building our journeys of faith from the standpoint of shame to that of redemption and grace. In the ascension of Christ, he promises the Holy Spirit who will continue to walk with us in the process of growing in our faith in God. We believe that this is what pastoral juxtaposition is all about. It invites the pastoral counsellor to take the form of an 'incarnate god', while partaking in the suffering of people who need a caregiving figure and also introducing them to the person of the Holy Spirit, one to whom the work of juxtaposition sees no end. Simkins' (1996:36) analysis of shame in the book of Joel gives a good summary of how shame is the consequence of 'the absence of God within the community'. This treatment of shame theory demonstrates how emotion and behaviour in terms of developing a caregiving faith have a reciprocal relationship in the world of the Bible and within church communities. Anderson (1991) reports that acts of joy and shame may have a correlation with the presence of God within the life of an individual or an imagined community. In other words, acts of joy are the proper response to the presence of God, whereas an absence of God's Spirit could lead to shame and feelings of anxiety, and may cumber spiritual growth. Secure attachment to God through the presence of the Holy Spirit in one's life could provide a stabilising and transformative effect for believers experiencing spiritual struggles.

Escaping the dangers of this world and reframing difficult stories to have a glimpse of hope may require proper engagement with the two proposed models (incarnation creativity and pneumatological spontaneity) of pastoral juxtaposition which are pivotal in terms of unlocking the difficult emotional padlocks that clamp spiritual growth within a redemptive community. Within the public arena, the values of honour and shame have both an individual and a corporate dimension. A person's identity is defined not only in terms of his or her own personal honour but also in terms 
of the collective honour of the group to which he or she belongs (Simkins 1996). God's incarnation story enables us, as members of a redemptive community, to partake in the suffering of one another as we enter the world order of conflict, identifying with others and bringing about lasting hope during a creative tension. This dimension of pastoral juxtaposition requires a great amount of humility, conviction and repentance. This can lead to the ultimate destination of incarnation creativity within a community context. In addition, such engagement requires what we call pneumatological spontaneity through being open-minded about the things of the Spirit. The openness to the Spirit enables the individual member to develop intimacy with the Triune God through the person of the Holy Spirit, who empowers the conflicted to move beyond past negative experiences and feelings of anxiety. Hence, pastoral juxtaposition in terms of incarnation creativity and pneumatological spontaneity creates an atmosphere of 'intimacy' and Divine love that helps the conflicted juxtapose their story within the context of a redemptive community.

Salvation is not a religious declaration, but an ontological reality that joins us together with the person of Christ in his death and resurrection. Christ's 'earthly walk' as God incarnate, and as the Son of God taking on a fleshly-bodily form (Jn 1:14), is a pure act of juxtaposition. This process of God-learning and experiencing the human predicament does not end with Christ's ascension. This work of juxtaposition is continued with the outpouring of the Holy Spirit (cf. Lk 24:24). The Holy Spirit continues the work of incarnation in the life of every believer in everyday life, as he baptises the believer into the work of Christ on the Cross, and guides, nurtures and fills us with power from above to grow in our relationship with the Father.

In a counselling relationship, the young person encounters God through human relationships that model healthy behaviours. As Wanak (2004) suggests:

God often breaks into our lives in the form of godly people. This is more than a 'knowing about,' it is the Spirit of God revealing himself through people. Each one of us, individually and corporately, is a curriculum, a course that reveals something of the nature of God; yes, mediated by frail humanity, but also empowered by the Spirit. (p. 59)

Man anthropomorphises God in this sense as God makes himself known through godly relationships within a church community:

Our impressions of God, particularly in our early years [of seeking him], are influenced by the godly (or ungodly) behaviour of significant others. An abusive and unloving [Christian other] may invalidate the fatherhood of God metaphor. (Wanak 2004:59)

But even in such abusive relationships, one may still maintain the impressions of an idealised father figure through proximal sources within their concentric environment. Godly role models rekindle the impressions of idealised father figures through their incarnated Christian lifestyle. Therefore, learning from godly figures, especially in the context of a church community, shapes godly behaviours that reflect the imago Dei (Wanak 2004).

\section{Pastoral juxtaposition in everyday life}

Over the years in talking with teens in trouble, one of the things often observed is that young people feel unworthy of God's love and mercy, especially when they have fallen short of a moral standard as established by the spiritual influencers in their life. This unworthiness often leads to feelings of anxiety and shame which hinders spiritual growth. By applying the pastoral theology of juxtaposition in spiritual care, the first task in helping a struggling youth would be to identify with them as Christ identified with humanity through incarnation. That is, find a way to meaningfully permeate the life of the youth so that they can know that they are not alone in their struggles. Unlike Christ, the pastoral counsellor is not a perfect vessel, but one who has experienced shame and guilt and therefore can relate to the life experience of the person in crisis. The creative process of incarnation can also take the form of validating the challenges of a conflicted youth while also pointing them to the incarnation story of the suffering Christ who having been tempted in every way just as they are yet emerged triumphant in the end (cf. Heb 4:15). This insight into the incarnated life of Christ, underscored by his earthly experience of suffering and triumph, creates the very creative container in which we can engage and transform the youth and help them forge their identity in Christ. Pastoral juxtaposition also points to the truth that we make our best work, and live our best lives, by charging into the power of the Holy Spirit who stands as our counsellor and advocate in times of conflict. The spiritual growth process is facilitated through the help of the Holy Spirit who directs and guides the youth in their journey of faith.

In addition, it is also possible that the proposed pastoral juxtaposition may not totally resolve the cognitive dissonance between the youth's story and God's story. Affirming the feelings experienced by the youth and at the same time conveying the story of God's grace through pastoral incarnation is a better approach of engagement in terms of collapsing the vast space between both God's story and youth's story. God's story is rooted in the idea that none of us is worthy. Yet despite our sinful nature, God's love in the person of Jesus and the Holy Spirit transforms us. Yong (2016:172) refers to this as an 'apostolic experience' with a Christological promise, given that it is pneumatological: the experience of the resurrected Christ is recounted as goodnews after Pentecost'. The promised Spirit of God released unto believers on the Day of Pentecost brought about power to fulfil the apostolic mission that would later make followers of Jesus shared witnesses to the world (cf. Lk 24:49; Ac 1:8; Ac 2:6, 7,12 ). Thus, we are enabled by the power of the Spirit to not only hear God's story, but also to become participants in this story as we fully embody the story of incarnation in the world.

Winnicott (1953) talks about what he refers to as the 'transitional phenomena', which was a term he used to describe the intermediate area of human experience that is 
in-between space. The notion of pastoral juxtaposition as a magnet space seems to belong to that inner reality and outside world. This is perhaps the power of juxtaposition because it speaks to us of a transitional world and holds out the promise that our rather self-destructive, chaotic experiences could become whole again as we engage with this in-between space of creative incarnation and pneumatological spontaneity. It would be a space in which we are at peace with our identity in Christ and in our relations with others and at one with the Spirit of God. The transformative power of this truth is not only inspirational, but also ontological. This means that the power of pastoral juxtaposition lies both in the ability to inspire the teen and in the work of the Holy Spirit to bring about genuine transformation of mind that can overcome past suffering.

It is noted that maintaining a relationship with God may not be realised outside the community of believers. Spiritual growth and intimacy with the Triune God is not complete until our story is juxtaposed within the context of a redemptive community. Ultimately, this may require identifying with people within the family of God who can walk with us as partners in faith, and to whom we can be accountable, as we grow in faith and maintain our relationship with God in everyday life. Pastoral counsellors within the context of an evangelical church community must exude qualities of pastoral incarnation as reliable figures who have laid down their lives to serve others and embody the presence of the Spirit of God as a demonstration of his power in their lives. These qualities ought to be found in Christian counsellors, youth leaders, church leaders or pastoral carers who engage in pastoral juxtaposition.

There is no end to the notion of pastoral juxtaposition. It could be a new way of thinking within the Body of Christ that makes each believer accountable to each other, and thus collapsing the vast space between one another. Pastoral juxtaposition recognises the relatedness of a creative incarnation and engagement with the Spirit in Christian counselling. How we go about managing these two relationships within a church community is an area of study open to further exploration with implication for both spiritual care and health care.

\section{Concluding remarks}

A proposal of pastoral juxtaposition has been used as a creative container in which the conflicting stories and biographies of young people can be reframed from a trinitarian perspective in such a way that promotes intimacy, identification and accountability in a spiritual healing context. Firstly, we argued that the spiritual struggles faced by young people may be traced to the history of their caregiving faith development, which is often a representation of their previous attachment experiences with primary caregivers, leading to insecure attachment to God representations and spiritual struggles. Secondly, we offered a pastoral theology for responding to youth caregiving faith experiences which first engages in an incarnation praxis that ensures that the pastoral counsellor or church community embodies the life of an 'incarnate figure' by entering the world order of the conflicted youth to identify with them as Christ did through his incarnation. This incarnation praxis in pastoral juxtaposition also points to the truth that we make our best work, and live our best lives, by charging into each other through the 'power of two'. This movement in the paper brings us to the next phase of pastoral juxtaposition, which is an attachment-affiliation with the person of Holy Spirit as our ultimate attachment figure, standing as our counsellor and advocate in times of conflict. Pastoral juxtaposition recognises the presence of the Holy Spirit in continuing the work of incarnation in terms of spiritual nurturing and fostering spiritual growth. However, while there might still be ambiguities around the proposed theology of pastoral juxtaposition, we invite other scholars to engage with this theological thought in order to give further clarity and help illuminate the importance of this theology for assuring and enhancing spiritual growth within and outside the context of a redemptive community.

\section{Acknowledgements Competing interests}

The authors declare that they have no financial or personal relationships which may have inappropriately influenced them in writing this article.

\section{Authors' contributions}

V.C. is the corresponding author and responsible for writing the initial conceptual draft and revising the final draft. J.R.M. is responsible for strengthening the paper with additional conceptual insights.

\section{References}

Aden, L.H. \& Hughes, R.G., 2002, Preaching God's compassion: Comforting those who suffer, Fortress Press, Minneapolis, MN.

Anderson, B., 1991, Imagined communities, rev. edn., Verso Books, London.

Ano, G.G. \& Pargament, K.I., 2013, 'Predictors of spiritual struggles: An exploratory study', Mental Health, Religion \& Culture 16(4), 419-434. https://doi.org/10.1080/ 13674676.2012.680434

Benner, D., 1983, 'The incarnation as a metaphor for psychotherapy', Journal of Psychology and Theology, 11(4), 287-294.

Benner, D., 2003, Strategic pastoral counseling, Baker Academic, Grand Rapids, MI.

Boccia, M.L., 2011, 'Human interpersonal relationships and the love of the trinity', Priscilla Papers 25, 22-26.

Bosch, D.J., 1991, Transforming mission, Orbis Books, New York.

Bowlby, J., 1969, Attachment and loss: Vol. 1. Loss, Basic Books, New York.

Bowlby, J., 1988, A secure base: Parent-child attachment and healthy human development, Basic Books, New York.

Bradshaw, M., Ellison, C.G. \& Marcum, J.P., 2010, 'Attachment to God, images of God, and psychological distress in a nationwide sample of Presbyterians', International Journal for the Psychology of Religion 20(2), 130-147. https://doi.org/ $10.1080 / 10508611003608049$

Bretherton, I. \& Munholland, K.A., 1999, 'Internal working models revisited', in J. Cassidy \& P.R. Shaver (eds.), Handbook of attachment: Theory, research, and clinical applications, pp. 89-111, Guilford Press, New York.

Bruner, F.D. \& Hordern, W., 1984, The Holy Spirit-shy member of the Trinity, Augsburg, Minneapolis, MN.

Cicirelli, V.G., 2004, 'God as the ultimate attachment figure for older adults', Attachment and Human Development 6(4), 371-388. https://doi.org/10.1080/ 1461673042000303091

Clinton, T., Hart, A. \& Ohlschlager, G., 2009, Caring for people God's way: Personal and emotional issues, Addictions, Grief, and Trauma, Thomas Nelson, Nashville, TN. 
Collins, G.R., 2006, Christian counseling: A comprehensive guide, 3rd edn., Thomas Nelson Publishers, Nashville, TN

Counted, V., 2016a, 'The psychology of youth faith formation: A care-giving faith?' Journal of Youth and Theology 15(2), 146-172. https://doi.org/10.1080/1461673 042000303091

Counted, V., 2016b, 'God as an attachment figure: A case study of the God attachment language and God concepts of anxiously attached Christian youth in South Africa', Journal of Spirituality in Mental Health 18(4), 316-346. https:// doi.org/10.1080/19349637.2016.1176757

Counted, V. \& Moustafa, A.A., 2017, 'Between God and self: Exploring the attachment to God and authenticity/inauthenticity tendencies of South African Christian youths', Mental Health, Religion \& Culture 20(2), 109-127. https://doi. org/10.1080/13674676.2017.1326476

Counted, V. \& Watts, F., 2017, 'Place attachment in the Bible: The role of attachment to sacred places in religious life', Journal of Psychology and Theology 45(3), 218-232.

Ellison, C.G., Bradshaw, M., Flannelly, K.J. \& Galek, K.C., 2014, 'Prayer, Attachment to God, and symptoms of anxiety-related disorders among U.S. Adults', Sociology of Religion 75(2), 208-233. https://doi.org/10.1093/socrel/srt079

Erikson, E., 1968, Identity, youth, and crisis, W.W. Norton Company, New York.

Exline, J.J., Homolka, S.J. \& Grubbs, J.B., 2013, 'Negative views of parents and struggles with God: An exploration of two mediators', Journal of Psychology and Theology $41(3), 200-212$

Fairbairn, W.R.D., 1952, Psychoanalytic studies of the personality, Tavistock, London.

Freud, S., 1927/1961, The future of an illusion, trans. J. Strachey, Norton, New York.

Granqvist, P. \& Kirkpatrick, L.A., 2016, 'Attachment and religious representations and behaviour', in J. Cassidy \& P.R. Shaver (eds.), Handbook of attachment: Theory, research, and clinical applications, 3rd edn., pp. 917-940, Guilford, New York.

Granqvist, P., Kirkpatrick, L.A., Mikulincer, M. \& Shaver, P.R., 2010, 'Religion as attachment: Normative processes and individual difference', Personality and Socia
Psychology Review 14(1), 49-59. https://doi.org/10.1177/1088868309348618

Hall, T.W., Fujikawa, A., Sarah, R.H. \& Hill, P.C., 2009, 'Attachment to God and implicit spirituality: Clarifying correspondence and compensation models', Journal of Psychology and Theology 37, 227-242.

Hardy, G. \& Barkman, M., 1994, 'The relationship between interpersonal attachmen styles and work difficulties', Human Relations 47, 263-281. https://doi.org/ 10.1177/001872679404700302

Hazan, C. \& Shaver, P., 1990, 'Love and work: An attachment-theoretical perspective', Journal of Personality and Social Psychology 59, 270-280. https://doi.org/ 10.1037/0022-3514.59.2.270

Hellerman, J.H., 2009, When the church was a family: Recapturing Jesus' vision for authentic Christian community, B \& H Academic, Nashville, TN.

Henry, C.F.H., 1999, God, revelation, and authority, Crossway Books, Wheaton, IL.

Holmes, B.M., 2009, 'Adult attachment and romantic partner preference: A review', Journal of Social and Personal Relationships 26(6-7), 833-852. https://doi.org/ 10.1177/0265407509345653

Hudson, N.W., Fraley, R.C., Brumbaugh, C.C. \& Vicary, A.M., 2014, 'Co-regulation in romantic partners' attachment styles: A longitudinal investigation' SocialPsychologyBulletin40,845-857.https://doi.org/10.1177/0146167214528989

Hunter, J.D., 1983, American evangelicalism: Conservative religion and the quandary of modernity, Rutgers University Press, New Brunswick, NJ.

Jones, J.W., 1996, Religion and psychology in transition: Psychoanalysis, feminism, and theology, Yale University Press, New Haven, CT.

Kärkkäinen, V., 2002, Pneumatology: The Holy Spirit in ecumenical, International, and contextual perspective, Baker Academic, Grand Rapids, MI.

Kaufman, G.D., 1981, The theological imagination: Constructing the concepts of God, Westminster, Philadelphia, PA

Kimball, C.N., 2001, in M.R. McMinn \& T.R. Phillips (eds.), Care for the soul: Exploring the intersection of psychology \& theology, pp. 346-362, IVP Academic, Downers Grove, IL.

Kimball, C.N., Boyatzis, C.J., Cook, K.V., Leonard, K.C. \& Flanagan, K.S., 2013 'Attachment to God: A qualitative exploration of emerging adults' spiritual relationship with God', Journal of Psychology and Theology 41(3), 175-88.

Kirkpatrick, L.A., 1992, 'An attachment-theory approach to the psychology of religion', The International Journal for the Psychology of Religion 2, 3-28. https://doi org/10.1207/s15327582ijpr0201_2

Kirkpatrick, L.A., 1998, 'God as a substitute attachment figure: A longitudinal study of adult attachment style and religious change in college students', Personality and adult attachment style and religious change in college students', Personality and
Social PsychologyBulletin 24,961-973. https://doi.org/10.1177/0146167298249004
Kirkpatrick, L.A., 1999, 'Attachment and religious representations and behaviour', in J. Cassidy \& P.R. Shaver, (eds.), Handbook of attachment theory and research, pp. 803-822, Guilford Press, New York.

Kirkpatrick, L.A., 2005, Attachment, evolution, and the psychology of religion, Guilford Press, New York.

Kirkpatrick, L.A. \& Shaver, P.R., 1990, 'Attachment theory and religion: Childhood attachments, religious beliefs, and conversion', Journal for the Scientific Study of Religion 29, 315-334. https://doi.org/10.2307/1386461

Kobak, R., Zajac, K. \& Madsen, S.D., 2016, 'Attachment disruptions, reparative processes, and psychopathology: Theoretical and clinical implications', in J. Cassidy \& P.R. Shaver (eds.), Handbook of attachment: Theory, research, and clinical applications, pp. 25-39, Guilford Press, New York.

Lorenz, K., 1935, 'Der Kumpan in der Umwelt des Vogels: Der Artgenosse als auslösendes Moment sozialer Verhaltensweisen', Journal für Ornithologie 83, 137-215. https://doi.org/10.1007/BF01905355

Miller, J.R., 2008, Have you not yet received the spirit? Finding unity through the Baptism in the Holy Spirit, Emerging Life Resources, CA.

Miller, J.R., 2017, Elders lead a healthy family: Shared leadership for a vibrant Church, Wipf and Stock, Salem, OR.

Oden, T.C., 1992, The word of life: Systematic theology, vol. II, Harper, San Francisco, CA.

O'Keefe, M., 1995, 'Predictors of child abuse in maritally violent families', Journa of Interpersonal Violence 10(1), 3-25. https://doi.org/10.1177/0886260950 10001001

Power, C.F., 1990, 'The distinctiveness of pastoral counseling', Counseling and Values 34, 75-89. https://doi.org/10.1002/j.2161-007X.1990.tb00908.x

Reinert, D.F., 2005, 'Spirituality, self-representations, and attachment to parents: A longitudinal study of Roman Catholic college seminarians', Counselling and Values 49(3), 226-38. https://doi.org/10.1002/j.2161-007X.2005.tb01025.x

Richert, R.A. \& Granqvist, P., 2013, 'Religion and spiritual development in childhood', in R.F. Paloutzian \& C.L. Park (eds.), Handbook of the psychology of religion and spirituality, pp. 165-182, Guildford Press, New York.

Ringel, S., 2008, 'Formative experiences of Orthodox Jewish women: Attachment patterns and spiritual development', Clinical Social Work Journal 36, 73-82. https://doi.org/10.1007/s10615-007-0112-6

Rizzuto, A.M., 1979, The birth of the living God: A psychoanalytical study, University of Chicago Press, Chicago, IL.

Rowatt, W. \& Kirkpatrick, L.A., 2002, 'Two dimensions of attachment to God and their relation to affect, religiosity, and personality constructs', Journal for the Scientific Study of Religion 41(4), 637-651. https://doi.org/10.1111/1468-5906.00143

Scannell, L. \& Gifford, R., 2010, 'Defining place attachment: A tripartite organizing framework', Journal of Environmental Psychology 30, 1-10. https://doi.org/ framework', Journal of Environ
10.1016/j.jenvp.2009.09.006

Schumacher, J.A. \& Leonard, K.E., 2005, 'Husbands' and wives' marital adjustment, verbal aggression, and physical aggression as longitudinal predictors of physical aggression in early marriage', Journal of Consulting and Clinical Psychology 73 28-37. https://doi.org/10.1037/0022-006X.73.1.28

Shenk, J.W., 2014, Powers of two: Finding the essence of innovation in creative pairs, Houghton Mifflin Harcourt, Boston, MA

Shenk, J.W., 2015, Powers of two: How relationships drive creativity, Mariner, New York.

Shin, H.J., 2009, 'Asian-American college students' parental attachment and their relationship with God', Christian Education Journal 6(2), 353-75.

Simkins, R.A., 1996, 'Return to Yahweh: Honor and shame in Joel', in V.H. Matthews \& D.C. Benjamin (eds.), Honor and shame in the World of the Bible, Semeia 68, pp. 41-54, Scholars Press, Atlanta, GA.

The Concise Oxford Dictionary, 1978, Evangelicalism, Oxford University Press, Oxford.

Wanak, L., 2004, 'Learning as the experience of God', Evangelical Review of Theology 28(1), 50-64.

Williams, R.J. \& Watts, F.N., 2014, 'Attributions in a spiritual healing context: An archival analysis of a 1920 s healing movement', Journal for the Scientific Study of Religion 53(1), 90-108. https://doi.org/10.1111/jssr.12085

Winnicott, D., 1953, 'Transitional objects and transitional phenomena', in Through paediatrics to psycho-analysis, pp. 229-242, Hogarth Press, London.

Yong, A., 2016, 'Reflecting and confessing in the Spirit: Called to transformational theologizing', International Review of Mission 105(2), 169-183. https://doi. org/10.1111/irom.12142 